\title{
Muráth Judit
}

Pécsi Tudományegyetem Közgazdaságtudományi Kar

PTE Egyetemi Könyvtár és Tudásközpont

Terminológiai Dokumentációs Központ

\section{A magyarországi szakszótárak és -lexikonok bibliográfiájának elektronikus adatbázisa}

\author{
https://doi.org/10.48040/PL.2020.14
}

\begin{abstract}
A magyarral kapcsolt szakszótári bibliográfia készitése a kezdetektöl (2006) alapfeladatként jelentkezett a pécsi Terminológiai Dokumentációs Központban, és a nemzetközi együttmüködés (Bécs-Köln-Pécs) megalakulásakor a nemzetközi team tagjai is célként tüzték ki. A pécsi központ feladata a magyarral kapcsolt szakszótári bibliográfia elkészitése a 16. századtól napjainkig, majd később a környezö országoké is. A terv digitális bibliográfia elkészitése volt. Közben a Magyar Tudományos Akadémia Szótári Munkabizottsága is sürgősen elvégzendö feladatnak határozta meg e kutatás véghezvitelét, hiszen Magay Tamás, a bizottság korábbi elnöke és tagja sok gyüjtő bevonásával már elvégezte a köznyelvi szótárak felkutatását, igy összeállt és nyomtatásban két izben meg is jelent az idevágó bibliográfia. A szakszótári bibliográfia a Pécsi Tudományegyetem Egyetemi Könyvtár és Tudásközpont támogatásával, a TermDok-Központ, ugyanakkor a Szótári Munkabizottság elgondolásainak összhangba hozásával is, digitális formában valósult meg. A tanulmány célja a fenti projekt bemutatása.
\end{abstract}

Kulcsszavak: bibliográfia, elektronikus bibliográfiai adatbázis, magyarországi szakszótárak és-lexikonok, szaklexikográfia, terminológia-dokumentáció, terminológia-menedzsment

\section{Bevezetés}

Amennyiben szótáraink és lexikonjaink megbízható adatok szolgáltatásával megpróbálnak lépést tartani a ránk zúduló információáradattal, fontos részét képezik egy-egy szakterület dokumentációjának, az adott szakterület tudásbázisának. Fontos tehát, hogy tudomást szerezzünk létezésükröl, és az érdekeltek számára hozzáférhetővé váljanak. Az 1989-es rendszerváltozást követően rendkívüli mértékben megnőtt a kiadott szótárak száma. Irodalmárok, nyelvészek, de legfőképpen lexikográfusok, valamint terminológusok tollából egyre több olyan publikáció jelent meg, amelynek középpontjában egy-egy szótár, szótárak vagy szótárkoncepciók álltak. Ugyanakkor hamar kiderült az is, hogy nincs teljes rálátásunk arra, milyen szótárakkal rendelkezünk már, és milyen további munkálatokra lesz még szükség. Ismerünk olyan bibliográfiákat (vö. pl. Sági, 1922; Kovács, 1963, 1965; BIB, 1965-1981; Magay, 1966), amelyek értékes információkat 
tartalmaznak, ezek azonban nem teljesek, hiszen korábbi korszakokban készültek, következésképpen nem tartalmazhatták még akkor az időközben kiadott munkákat. Szükség volt tehát az elődök által megkezdett gyüjtőmunka folytatására, a már meglévő adatok kiegészítésére. A Magyar Tudományos Akadémia I. Osztálya Nyelvtudományi Bizottságának Szótári Munkabizottsága 2000-ben újjáalakult, és első fontos célkitüzései között a magyar szótárirodalom bibliográfiájának elkészítése szerepelt. A köznyelvi szótárak bibliográfiája új gyüjtés eredményeként, sok gyüjtő bevonásával, Magay Tamás, az újjáalakult bizottság első elnökének koordinálásával elkészült, és könyvformátumban, két ízben meg is jelent (Magay, 2003, 2011). A következő lépés a szakszótári bibliográfia elkészítése, amely a Bizottság elgondolásával összhangban a PTE Egyetemi Könyvtár és Tudásközpont Terminológiai Dokumentációs Központjában, az Egyetemi Könyvtár és Tudásközpont támogatásával készül.

\section{Az adatbázis - dilemmák és megvalósítás}

\section{Elözmények}

A 2006-ban, Pécsett megalapított Terminológiai Dokumentációs Központ (TermDok) különösen dokumentációs tevékenységével kívánja a magyarországi terminológia ügyét szolgálni. Ezek közé tartozik többek között a magyar és nemzetközi terminológiai publikációk, egy-, két- és többnyelvü terminológiai szótárak, szakszótárak gyüjtése, a nehezen hozzáférhető anyagok digitalizálása etc. (vö. Muráth, 2013). A központnak az utóbbi években kiemelt kutatási és dokumentációs tevékenysége magyarországi kutatók munkájának bevonásával - a magyarországi szaklexikográfiai aktivitások dokumentálása, bibliográfia és tanulmánykötet formájában (Arató - Muráth, 2019; Muráth, 2020).

Ahhoz, hogy tudjuk, mi van birtokunkban, és milyen további munkálatokra van szükség, megkerülhetetlen a meglévő értékek felleltározása. Fontos forrásként tartjuk számon a fentebb említett, korábban készült bibliográfiákat, amelyek különböző korszakokban készültek. Az első, Sági István bibliográfiája, amely összesen 479 tételt tartalmaz, a kezdetektől 1922-ig vette számba a magyarral kapcsolt szótárakat. Külön tárgyalja az egynyelvü, valamint a két- és többnyelvü szótárakat. Utóbbiakat három csoportra osztja, ezek a köznyelvi szótárak, a szak- és müszótárak, valamint a szólás- és közmondás-gyüjtemények (Sági, 1922). Kovács Zoltán - a hazai szláv nyelvủ lexikográfiát bemutató - két tanulmányában és az azokhoz csatolt bibliográfiákban (Kovács, 1963, 1965) a köznyelvi szótárakat és a szakszótárakat is lajstromozza, a kezdetektől egészen 1962-ig. Ugyanekkor jelenik meg Magay Tamás tanulmánya is, amely az 1945-1964-ig tartó 
időszakban publikált magyar szótártani irodalom könyvészetét gyüjti egybe. Jóllehet ez utóbbi munkák a szótárírás elvi vagy gyakorlati kérdéseivel foglalkoznak, a bibliográfia azonban minden esetben meghivatkozza azokat a szótárakat is, amelyek az értekezés tárgyát képezik. Előbbiek között szerepelnek értelmező, valamint két- és többnyelvü szakszótárak is (Magay, 1966). Az ún. szocialista országok bibliográfiájának kilenc kötete is értékes forrás, amelyben az 1945 és 1978 között Magyarországon kiadott egy-, kétés többnyelvű szótárak - legyenek azok köznyelvi vagy szakszótárak számbavétele is évröl-évre folyamatosan történik (BIB, 1965-1981).

A bibliográfia elkészítésében, a pontos adatok közlésében jelentős szerepet játszanak továbbá azok a szaklexikográfiai és terminológiai kutatások, amelyeket a gyüjtőmunkában részt vevő kutatók végeztek és végeznek (vö. Bérces, 2006; Czékmán, 2010; Fogarasi et al., 2020; Muráth, 2003; Seidl-Péch et al., 2014; Szamosmenti et al., 2014), s amelynek eredményeként sikerül teljesebb képet kapni a különböző szakterületek szókincsét feldolgozó munkákról.

\section{Nyomtatott vagy digitális?}

A legelső, és a projekt koncepciójának kialakítása szempontjából kardinális kérdés volt, hogy milyen formátumban tegyük közzé a kutatómunka eredményeit: nyomtatott könyv készüljön vagy elektronikus adatbázis? Mivel a köznyelvi szótárak bibliográfiája nyomtatott formában és a Bizottság Lexikográfiai füzetek sorozatának kiadványaként jelent meg, logikusnak tünt papírformátumban gondolkodni. Az elektronikus adatbázis mellett azonban több nyomós érv is szólt. Az első és legfontosabb érv volt, amely már a köznyelvi szótárak gyűjtésekor világossá vált, hogy szinte lehetetlen tökéletes bibliográfiát létrehozni, azt újra meg újra bővíteni kell az időközben felfedezett szótárak esetében, és az idő múlásával is újabb szótárak jelennek meg. Mindez fokozottan érvényes a szakszótárakra, hiszen hihetetlenül szerteágazó területeket kell egybefogni. Egy ilyen folyton változó és sokrétü adathalmaz esetében előnyösebb a folyamatosan bővíthető adatbázis, mint lehetőség. A papír kiiktatásával a könyvnyomtatással járó költségeket is megtakarítjuk, és nem utolsó sorban a szinte korlátlanul rendelkezésre álló tárhely lehetővé teszi az egy-egy konkrét szótárral kapcsolatos minél részletesebb információk közlését.

\section{A koncepció megalkotását befolyásoló, a tartalomra vonatkozó döntések}

A következö, de nem kevésbé fontos kérdés volt, hogy mit vegyünk fel a bibliográfiába? A cél a teljes bibliográfia elkészítése. Ez azt jelenti, hogy valamennyi szakterületen elkészült munkákat kell egybegyüjteni. Itt már 
valamiféle rendszer felállításának kérdése is felmerül, hiszen a szakterületek és azok további alterületeinek száma végtelen. Természetesen nem biztos, hogy esetünkben minden szakterület számára készült szókincs- vagy terminológiai gyüjtemény, de egy adott rendszerbe a meglévők jól beilleszthetők. E meggondolások tezauruszok, különböző terminológiai kategorizálások, európai uniós fordítószolgálatok, valamint nemzetközi könyvtári osztályozási rendszereinek megismerésére és esetleges felhasználására irányították a figyelmet. A nemzetközi partnereinkkel Christian Galinski, Infoterm Bécs, Klaus-Dirk Schmitz, Fachhochschule Köln - 2012-ben, Pécsett tartott közös ülésünkön is több klasszifikációs rendszer előnyeit és hátrányait vitattuk meg. Végül a pécsi team a legkézenfekvőbb megoldás mellett döntött. A magyarországi könyvtárak zömében és a világ nagyon sok könyvtárában használatos, a két belga tudós - Otlet és La Fontaine - által, a Dewey-féle osztályozásból ${ }^{1}$ továbbfejlesztett, elöször 1905-ben, Brüsszelben kiadott rendszere, az UDC (Universal Decimal Classification), magyarul az Egyetemes Tizedes Osztályozás (ETO). Az ETO az a nemzetközi osztályozási rendszer, amelynek segítségével a könyvtárak a dokumentumokat tartalmuk szerint csoportosítják és osztályokba rendezik (vö. UDC, ETO). Noha az ETO-t - föleg az utóbbi időben - sok és jogos kritika érte, többek között az, hogy nem felel meg a mai kor követelményeinek, mégis úgy határoztunk, hogy a kutatásban és a bibliográfia készítésében a kritikus hangok ellenére az ETO-ra támaszkodunk. Ugyanis rendszerbe foglalva tartalmazza a lehető legtöbb szakterületet, egyértelmü, rugalmas, bővíthető, így az időközben kialakult szakterületek beilleszthetők a már meglévők közé.

Nagy körültekintést igényelt annak az eldöntése is, hogy milyen dokumentumokat gyüjtsünk. Ez a látszatra rendkívül egyszerủen megválaszolhatónak tünő kérdés a magyarországi és a nemzetközi lexikográfia elméletét tekintve több további kérdést vetett fel. Természetesen szótárt, azaz szakszótárt, mondhatnánk. De mi is a szótár? „Lexikának nevezzük a nyelv szavainak és szólásainak összességét, sajátosan jelentésükben tekintve őket, szótárnak pedig azokat a könyveket, amelyek egy nyelvnek vagy valamely rétegének lexikáját nyilvántartják és értelmezik, magyarázzák" (Migliorini, 1951)². Migliorini a szótárak két jellemzőjét emeli ki: 1) egy bizonyos lexika nyilvántartása; 2) annak értelmezése, magyarázása. Az értelmezés történhet úgy, hogy az adott nyelven magyarázatot füzünk az adott szóhoz vagy kifejezéshez, de úgy is, hogy megadjuk egy másik nyelven

\footnotetext{
${ }^{1}$ A tizedes osztályozás eredeti összeállítója Leibniz (1646-1716), akinek az ötletét az amerikai könyvtáros, Dewey (1851-1931) vette át és fejlesztette tovább Dewey Decimal Classification (DDC) név alatt.

${ }^{2}$ Fordította Kovalovszky Miklós (Kovalovszky, 1966:123).
} 
a megfelelöjét. Ennek alapján beszélünk egynyelvü (értelmezö) vagy két- és többnyelvü szótárakról.

Mi is a szakszótár? A szakszótár nem a köznyelv, hanem egy-egy kisebb vagy nagyobb szakterület lexikáját gyüjti egybe, és közöl ehhez a lexikához tartozó információkat. Aki valamilyen szakterületen tevékenykedik - legyen az az adott terület szakembere, mérnöknek, orvosnak, jogásznak, közgazdásznak etc. készülő diák, valamilyen szakterületen tevékenykedő oktató, kutató vagy fordító -, tisztában van azzal, hogy különösen egy-egy szakterület számára készült munkák esetében jelentős szerepe van a nyelvi (anyanyelvi, helyesírási etc. információ és idegen nyelvi megfelelö) információkon túl a szakmai információnak is, amelyet enciklopédikus információnak nevezünk. Ez lehet rövid magyarázat vagy mélyebb értelmezés is, amelyre nagy szükség van, mivel az anyanyelvét beszélő eltekintve az adott terület kész szakemberétől - önmagában az anyanyelv ismerete alapján még nem szakértője egy-egy területnek, csupán idővel válik azzá. Mindezek alapján O. Nagy, Wiegand és Klein elméletét elfogadva

\begin{abstract}
„,...szakszótárakon olyan egynyelvü, kétnyelvü vagy többnyelvü referenciamüveket értünk, amelyek létrejötte szakmai-tudományos munkát elöfeltételez, és azzal a céllal készülnek, hogy használóik belölük speciális szakszókinccsel és/vagy szakmai ismeretekkel kapcsolatos információkat merithessenek. E müvek tehát - alfabetikus vagy tematikus rendben - szavak/kifejezések jegyzékét tartalmazzák, és direkt vagy indirekt módon szakmai-tudományos magyarázatokkal is el vannak látva” (Klein, 1999:1910, vö. még O. Nagy, 1970; Wiegand, 1988; Muráth, 2002, 2010:39; 2020a:9).
\end{abstract}

Wiegand szakszótár-tipológiájára támaszkodva, Fata - Muráth (2020:40) alapján a szakszótáraknak három csoportját különböztetjük meg:

1. ábra. A wiegandi elvekre épülő szakszótártipológia

(Wiegand, 1988; vö. még Felber/Schaeder, 1999:1731; Muráth, 2002:26, 2010:39; Magay, 2015:13)

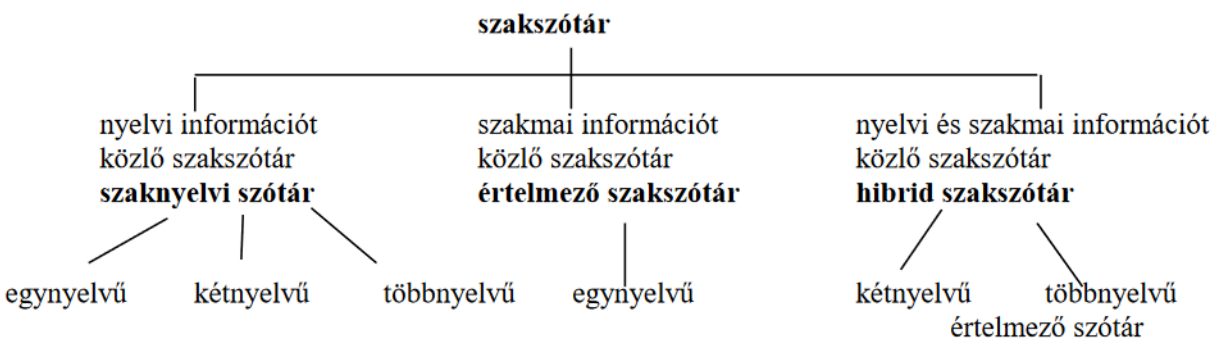


Mindhárom típusra látunk példákat a magyar szaklexikográfiában is (vö. Muráth, 2002; Bérces, 2006; Czékmán, 2010; Fata - Muráth, 2020:39; Fogarasi et al., 2020). A második kategória, azaz a szakmai információt közlő értelmező szakszótárak és az egy-egy szakma számára készült lexikonok között elmosódnak a határok, hiszen a lexikon első jelentése a Magyar Értelmezö Kéziszótár szerint „1. Vmennyi v. egy-egy szaktudomány körébe tartozó ismereteket betürendbe sorolt kisebb cikkekben közlö (többkötetes) kézikönyv" (MÉK, 2003:836), amely ugyancsak szakmai információkat közöl egy-egy címszóról. Mivel egy-egy szakterület szakszókincsének egybegyüjtését és értelmezését nem csupán az egy-, két- és többnyelvü szakszótárak, terminológiai szótárak, hanem a szaklexikonok is felvállalják, következésképpen egy-egy adott szakterület szakemberei, az adott területet tanulmányozó diákok, fordítók a lexikonokhoz is fordulnak segítségért. Mindezt figyelembe véve bibliográfiánk mind a szakszótárak, mind a szaklexikonok egybegyüjtését célul tüzte ki.

A szótári bibliográfiák általában az önálló szótárakat lajstromozzák, és az integrált szótárak (tankönyvek szójegyzékei, jogszabályok terminológiai jegyzékei stb.) nem képezik részét ezeknek a gyűjteményeknek. Ezzel ellentétben az integrált szótárak felvételét is fontosnak tartjuk, ugyanis bizonyos szakkönyvek sok esetben értékes szakszógyüjteményeket tartalmaznak, amelyeknek ezért a bibliográfiában a helyük. Az adatbázisban egy-egy rekord részletező adatai révén a pontos adatolás ebben az esetben is lehetségessé vált.

A fentiek értelmében a bibliográfiába hordozótól függetlenül önálló és integrált szótárakat egyaránt felveszünk, szakszótárakat és terminológiai szótárakat, abc- vagy tematikus rendben megalkotott egy-, két- és többnyelvü szaknyelvi szótárakat, értelmező szakszótárakat, hibrid szakszótárakat és szaklexikonokat.

\section{Milyen időszak szótárai kerüljenek be a bibliográfiába?}

A cél a teljes bibliográfia elkészítése, a kezdetektől napjainkig. A kutatás mostani szakaszában azonban a hangsúly az utóbbi 75 év, tehát az 1945 és 2019 között kiadott szakszótárak és - lexikonok adatainak felvitelén volt. Mivel ezek a munkák könyvtárainkban kevés kivételtől eltekintve ott vannak a polcokon, teljesíteni tudtuk azt a fontos kritériumot, hogy szinte minden kötetet kézbe tudtunk venni, és pontos adatokat tudtunk az adatbázisba felvinni. Így csak kivételes esetben kellett közvetett bibliográfiai forráshoz nyúlni. Ezt követően tértünk rá az 1945 előtt megjelent müvek adatainak rögzítésére, amelyek munkálatai tovább folytatódnak. 
Milyen adatokat közöl a bibliográfia?

Egy-egy adatlap a következö, részletes információkat tartalmazza:

Az adatlap bal felső sarkában az alábbi piktogramokat találjuk: a szókincs rendszerezésére utaló piktogram (abc-rend, tematikus); a szókincsre vonatkozó definíció vagy magyarázat: egy könyvet ábrázoló piktogram; ha a dokumentum ábrát tartalmaz: az ábrákra utaló piktogram.

További adatok: cím, alcím, fordítás esetén az eredeti cím is; szerző vagy szerkesztő (esetleg fordító, munkatárs); tudományterület, tárgynyelv/ tárgynyelvek, tárgyszavak, kiadó, kiadás helye és száma, típusa (nyomtatott vagy elektronikus); sorozat esetén a sorozat címe és száma, ISBN / ISSN / DOI, kép a borítóról, annotáció, megjegyzés, a rekordok száma (amennyiben lehetséges), internetes elérés, a gyűjtő szignója.

\section{A közremüködök és a jelenleg kutatott területek}

Az adatbázis szoftverfejlesztője Takács Ákos, az Egyetemi Könyvtár és Tudásközpont informatikusa. A szerkesztők, egyben lektorok Arató Balázs és Muráth Judit. A kutatás jelenlegi szakaszában kutatóink az alábbi szakterületek dokumentumainak adatait gyüjtötték egybe:

- Arató Balázs és Révész Eszter: Európai Unió, kultúra, jogtudomány, államigazgatás, közigazgatás, politika, történelem, hadügy, hadtudomány, vallás, teológia;

- Bérces Edit: sport;

- Czékmán Orsolya: matematika;

- Fogarasi Katalin: orvos- és egészségtudomány, pszichológia, biológia, természetgyógyászat;

- Magay Tamás: szakszótárak 1945-től 1978-ig, valamint útiszótárak;

- Muráth Judit: gazdaság, közgazdaságtudomány, mezőgazdaság, környezetvédelem, könyvészet, könyvtár, nyomdaipar, hadügy, hadtudomány, zene;

- Seidl-Péch Olívia: müszaki tudományok;

- Szamosmenti Marianne: gazdaság, gazdaságtudományok angolmagyar vonatkozásban.

A jelenleg publikált és mindenki számára hozzáférhető adatlapok száma 719 , további 30 adatlap vár még kiegészítésre. Néhány szakterületen 
különösen nagyszámú szakszótárt és -lexikont adtak ki, erről a Publikált kategóriában a 147 gazdasági, közgazdaságtudományi, a 116 orvos- és egészségtudományi, a 108 müszaki tudományok, valamint a 101 zenei adatlap tanúskodik.

\section{Keresés és a találatok böngészése}

Az adatbázis elérhetősége: https://szakszotar.lib.pte.hu. A keresés kétféleképpen történhet: a) az Egyszerü keresés funkciót használva a szótárak adataiban előforduló kifejezésekre kereshet az érdeklődő; b) az Összetett keresés funkciót választva három mezőben további szempontok is megadhatók. A Mező listából kiválasztható, milyen információ (pl. szerző, szerkesztő, munkatárs, kiadás, helye, éve, hordozó, kötet száma, rekordok száma, rendszerezés típusa, teljes mü terjedelme, szótári rész terjedelme, tárgynyelv, tárgyszó, ISSN, ISBN, DOI etc.) alapján kívánja szürni a szótárakat. Az Operátor mező esetében választhat az Egyenlő és Tartalmazza lehetőségek között is, majd az Érték szövegmezőbe beírhatja a keresett kifejezést, vagy választhat előre meghatározott értékek közül. Ha még pontosabb szürésre van szükség, akkor az Új hozzáadása gombra kattintva további feltételek megadására van lehetőség. Ekkor a rendszer kiszüri és csak azokat a szótárakat mutatja, amelyekre az összes feltétel érvényes. A Keresés gombra kattintva indítható el a keresés. Ekkor egyszerre maximum 50 szótár címe jelenik meg abc-rendben. Több találat esetén az érdeklődő navigálhat a találatok oldalai között. Mint már említettük, a szótárakra vonatkozó adatokat piktogramok is segítik, amelyek utalnak arra, hogy a rendszerezés típusa abcrend vagy tematikus, van-e definíció vagy magyarázat, illetve van-e ábra a szótárban. A szótár címére kattintva megnyitható az annak részletes adatait tartalmazó adatlap.

\section{Kitekintés}

A 2019 szeptemberében megnyitott és minden érdeklődő számára hozzáférhetővé vált adatbázis a kutatás első szakaszának eredményeit tartalmazza. A munka tehát folytatódik. Egyrészt tovább keressük és vizsgáljuk a már eddig feltárt szakterületek dokumentumait, miközben ezúttal az 1945 előtt megjelent dokumentumokra koncentrálunk, másrészt kiterjesztjük vizsgálatainkat további, eddig még nem vizsgált szakterületekre. A harmadik célkitüzés pedig a határainkon túl keletkezett, magyarral kapcsolt szakszótárak és -lexikonok adatainak egybegyüjtése. E munkálatok elvégzése után tudunk szakszótárainkról és -lexikonjainkról teljes képet adni. 


\section{Hivatkozások}

Bérces, E. (2006): A sportlexikográfia és -terminológia az új sportágak megjelenésének tükrében. PTE: Pécs, Phd-értekezés

BIB 1965-1981 = Rymsza-Zalewska, D. - Siedlecka, I. et al. (eds) (1965-1981):

Bibliographie der Wörterbücher/Bibliography of Dictionaries vom Band 1-9.

Wydawnictva Naukowo-Techniczne: Warszawa

Czékmán, O. (2010): Vizsgálatok a magyar matematikai terminológia tárgykörében. Pannon Egyetem: Veszprém, Phd-értekezés

Fata, I. - Muráth, J. (2020): A magyarországi meta-szaklexikográfiai kutatásokról. In: Muráth, J. (szerk.): Magyar szaklexikográfia. (Lexikográfiai füzetek 10.) Tinta Könyvkiadó: Budapest. 37-74

Felber, H. - Schaeder, B. (1999): Typologie der Fachwörterbücher. In: Hoffmann, L. Kalverkämper, H. - Wiegand, H. E. (Hrsg.) In Verbindung mit Galinski, Ch. Hüllen, W. (1999): HSK 14. Fachsprachen: ein internationales Handbuch zur Fachsprachenforschung und Terminologiewissenschaft. Band 14.2. Walter de Gruyter: Berlin-New York. 1725-1743

Fogarasi, K. - Zrínyi, A. - Meiszter, E. (2020) A magyar orvosi szaknyelv szaklexikográfiája. In: Muráth, J. (szerk.) (2020): Magyar szaklexikográfia. (Lexikográfiai füzetek 10.). Tinta Könyvkiadó: Budapest. 302-321

Klein, W. P. (1999): Formen der Fachlexikographie in der vorindustriellen Zeit: eine historische Übersicht. In: Hoffmann, L. - Kalverkämper, H. - Wiegand H. E. (Hrsg.) (1998-1999) HSK 14. Fachsprachen: ein internationales Handbuch zur Fachsprachenforschung und Terminologiewissenschaft. 2. Teilband: 1910-1925

Kovalovszky, M. (1966): Nyelvi elemek stiláris értéke a szótárakban. In: Országh, L. (szerk.): Szótártani tanulmányok. Tankönyvkiadó: Budapest. 123-147

Kovács, Z. (1963): A hazai szláv nyelvü lexikográfia (1945-től, 1962 májusáig). In: Az Országos Széchényi Könyvtár Évkönyve 1961-62. OSZK: Budapest. 371-383

Kovács, Z. (1965): Szláv nyelvű szótárírás Magyarországon a kezdetektől 1945-ig. In: Az Országos Széchényi Könyvtár évkönyve 1965. 482-490

Magay, T. (1966): A magyar szótártani irodalom könyvészete 1945-től 1964-ig. In: Országh, L. (szerk.) (1966): Szótártani tanulmányok. Tankönyvkiadó: Budapest. 369-396

Magay, T. (2003, 2011²): A magyar szótárirodalom bibliográfiája. (Lexikográfiai füzetek 1.) Akadémiai Kiadó: Budapest

Magay, T. (2015): Szótár, enciklopédia és tipológia. In: Fábián, Zs. - Szöllősy, É. (szerk.): Szótár, lexikon, enciklopédia. Kérdések és feladatok. (Segédkönyvek a nyelvészet tanulmányozásához 172.) Tinta Könyvkiadó: Budapest. 9-16

MÉK 2003 = Pusztai, F. (főszerk.) (2003): Magyar értelmező kéziszótár. Akadémiai Kiadó: Budapest

Migliorini, B. (1951): Che cos' è un vocabolario? Le Monnier: Firenze

Muráth, J. (2002 [2003]): Zweisprachige Fachlexikographie. (PBS 5). Universitas. Nemzeti Tankönyvkiadó: Budapest

Muráth, J. (2010): Szaknyelv és lexikográfia. In: Dobos, Cs. (szerk.): Szaknyelvi kommunikáció. Segédkönyvek a nyelvészet tanulmányozásához 110.. Miskolci Egyetem-Tinta Könyvkiadó: Miskolc-Budapest. 23-50

Muráth, J. (2013): Terminológia-dokumentáció nemzetközi együttműködésben. In: Silye, M. (szerk.) (2013): Innováció és nemzetközi együttmüködés a szaknyelv oktatásában és kutatásában. Porta Lingua-2013 SZOKOE: Debrecen. 205-210 
Muráth, J. (szerk.) (2020): Magyar szaklexikográfia. Lexikográfiai füzetek 10.. Tinta Könyvkiadó: Budapest

Muráth, J. (2020a): A magyar szaklexikográfia - történeti áttekintés. In: Muráth, J. (szerk.) (2020): Magyar szaklexikográfia. (Lexikográfiai füzetek 10.) Tinta Könyvkiadó:

Budapest. 9-36

O. Nagy, G. (1970): Szótártípusok. Magyar Nyelv. 66. 135-146

Országh, L. (szerk.) (1966): Szótártani tanulmányok. Tankönyvkiadó: Budapest

Sági, I. (1922): A magyar szótárak és nyelvtanok könyvészete. A Magyar Nyelvtudományi

Társaság Kiadványai, 18. Magyar Nyelvtudományi Társaság: Budapest

Seidl-Péch, O. - Pálinkás, M. (2014): Mono-, Bi- and Multilingual Technological

Dictionaries in Hungary. In: Muráth, J. (ed.) (2014): Hungarian Lexicography III.

LSP Lexicography. (Lexikográfiai füzetek 7.) Akadémiai Kiadó: Budapest. 343-379

Szamosmenti, M. - Csák, É. - Kriston, R. (2014): Wörterbücher des Wirtschaftswesens mit Ungarisch. In Muráth, J. (ed.) (2014): Hungarian Lexicography III. LSP

Lexicography. Lexikográfiai füzetek 7. Akadémiai Kiadó: Budapest. 381-424

Wiegand, H. E. (1988): Was eigentlich ist Fachlexikographie? In: Haider-Munske, H. et al. (Hrsg.): Deutscher Wortschatz. Lexikologische Studien. Walter de Gruyter: BerlinNew York.729-790

\section{Internetes források}

Arató, B. - Muráth, J. (szerk.) (2019): A magyarországi szakszótárak és -lexikonok bibliográfiája. https://szakszotar.lib.pte.hu

ETO = Veredy, Gy. (szerk.) (1958): Egyetemes Tizedes Osztályozás. A nemzetközi táblázatok hivatalos magyar kivonata. Bibliotheca Kiadó: Budapest https://mek.oszk.hu/19600/19690/19690.pdf

$\mathrm{UDC}=\underline{\mathrm{www}} \cdot \mathrm{udcc} \cdot \mathrm{org}$ 